\title{
Effect of Cinnamon Powder Addition on Microbial Quality of Fresh Buttermilk
}

\author{
Sutar Pritee Sanjay ${ }^{1}$, Shakeel Asgar ${ }^{2}$, Diwakar Mishra ${ }^{3 *}$, \\ S. D. Kalyankar ${ }^{1}$ and M. R. Patil ${ }^{1}$
}

${ }^{1}$ College of Dairy Technology, Udgir, Maharashtra, India

${ }^{2}$ College of Dairy Science and Food Technology, Raipur, Chhattisgarh, India

${ }^{3}$ Phulo-Jhano Murmu College of Dairy Technology, Dumka, Jharkhand, India

*Corresponding author

\section{A B S T R A C T}

\begin{tabular}{l} 
K e y w or d s \\
$\begin{array}{l}\text { Buttermilk, Spices, } \\
\text { Cinnamon, Shelf } \\
\text { life, SPC }\end{array}$ \\
Article Info \\
$\begin{array}{l}\text { Accepted: } \\
15 \text { September } 2020 \\
\text { Available Online: } \\
10 \text { October } 2020\end{array}$ \\
\hline
\end{tabular}

\section{Introduction}

Buttermilk is a one of the mostly used by product of the milk which is prepared by churning of cream in butter making process. This contains lipids, proteins and vitamins which are water soluble (Hunziker, 1923). It has mild pleasing flavour resulting from a blend of clean acid taste and delicate aromatic flavour and it should be free from off flavours like flat, metallic, yeasty or bitterness. It is one of the best among milk products due to its immense therapeutic and nutritional value (Sarkar, 2008). Regular use of buttermilk immensely helps the jaundice and alcoholic liver patients to regain normal appetite and digestion (Trivedi, 1971; Anon, 2003). Fermented milk products have been observed to provide anticholesterolaemic effect (Mann and Sperry, 1974; Thakur and Jha, 1981; and Chawla and Kansal, 1983); they stimulate natural activities of the body cells and consequently strengthen the immune system. They also protect against urogenital infection, break down carcinogenic substances, provide relief from constipation and diarrhoeal disorders, lower serum cholesterol level, inhibit the mutagenicity of the intestinal 
contents, reduce the incidence of intestinal tumor, inhibit decalcification of bones in elderly people and aid in the treatment of ulcer (Sarkar, 2002).

Spices have been well-known for their medicinal, preservative and antioxidant properties (Souza et al., 2005). They are currently used mainly for enhancing the flavor of foods rather than extending shelf life (Almeida and Regitano, 2000). In addition to imparting flavor, certain spices prolong the shelf life of foods due to their bacteriostatic or bactericidal activity, and some prevent rancidity by their antioxidant activity (Shelef, 1984). Many plant essential oils of spices are active against various food borne bacteria and molds (Aureli et al., 1992). Spices in general show antimicrobial activity due to phenolic component (Deans et al., 1995). The ability of phenolics to interfere with cellular metabolism through a number of mechanisms (substrate complexing, membrane disruption, enzyme inactivation and metal chelation) is well known (Cowan, 1999). The bark of various cinnamon species is one of the most important and popular spices used worldwide not only for cooking but also in traditional and modern medicines. Over all, approximately 250 species have been identified among the cinnamon genus, with trees being scattered all over the world (Vangalapati et al., 2012). Cinnamon (Cinnamomum zeylanicum) comes from the bark of a small Southest Asian evergreen tree and is available as oil, extract, dried powder or sticks. The word cinnamon comes from the Greek Kinnamomon (Maheshwari et al., 2013). Cinnamicaldehyde, the principle component of cinnamon oil, at $150 \mathrm{ppm}$ inhibited the growth and toxin production of Aspergillusparsiticus in candies and baked goods. Cinnamon has antimicrobial property against Compylobacter jejuni, Salmonella enteritidis, E. coli, Staphylococcus aureus and listeria monocytogenes. Present study was conducted to investigate the effect of cinnamon powder addition on microbial quality of fresh buttermilk.

\section{Materials and Methods}

The samples of buttermilk with cinnamon were analysed for the following microbial parameters.

\section{Standard plate count}

The standard plate count in buttermilk was determined as per the standard procedure (APHA, 1992).

\section{Yeast and mould count}

The yeast and mould count for buttermilk was determined by using procedure recommended by APHA (1992).

\section{Results and Discussion}

In fresh buttermilk, cumin, cinnamon and black salt were added. In every treatment, percentage of black salt and cumin were constant, while percentage of cinnamon in buttermilk was different (Table 1). Table 1 shows combination of spices at different levels in buttermilk. The percentage of cinnamon powder was $0,0.5,1$ and 1.5 in the $\mathrm{T}_{0}$ (control), $\mathrm{T}_{1}, \mathrm{~T}_{2}$ and $\mathrm{T}_{3}$.

\section{Standard Plate Count (SPC)}

The effect of cinnamon powder addition on standard plate count of buttermilk is shown in Fig. 1. The average values of SPC of different samples $T_{0}, T_{1}, T_{2}$ and $T_{3}$ was determined were $4.49,4.42,4.38$ and $4.35 \mathrm{cfu} / \mathrm{g}$ respectively.

The maximum SPC was 4.49 in the sample $\mathrm{T}_{0}$, while the minimum count of 4.35 was in the sample $\mathrm{T}_{3}$. The reduction in standard plate 
count in buttermilk may be due to antimicrobial property of cinnamon. Agaoglu et al., (2007) reported the antimicrobial activity of cinnamon in meat products.
Vidanagamage (2016) found lower standard plate count in butter added with cinnamon extract.

Table.1 Combination of spices at different levels in buttermilk

\begin{tabular}{|c|c|c|c|c|}
\hline Treatments & Buttermilk (\%) & Cinnamon powder (\%) & Black salt (\%) & Cumin (\%) \\
\hline $\mathbf{T}_{\mathbf{0}}(\mathbf{C o n t r o l})$ & 99.2 & 0 & 0.4 & 0.4 \\
\hline $\mathbf{T}_{\mathbf{1}}$ & 98.7 & 0.5 & 0.4 & 0.4 \\
\hline $\mathbf{T}_{\mathbf{2}}$ & 98.2 & 1 & 0.4 & 0.4 \\
\hline $\mathbf{T}_{\mathbf{3}}$ & 97.7 & 1.5 & 0.4 & 0.4 \\
\hline
\end{tabular}

Fig.1 Changes in standard plate count (cfu/g) of buttermilk added with different level of cinnamon powder

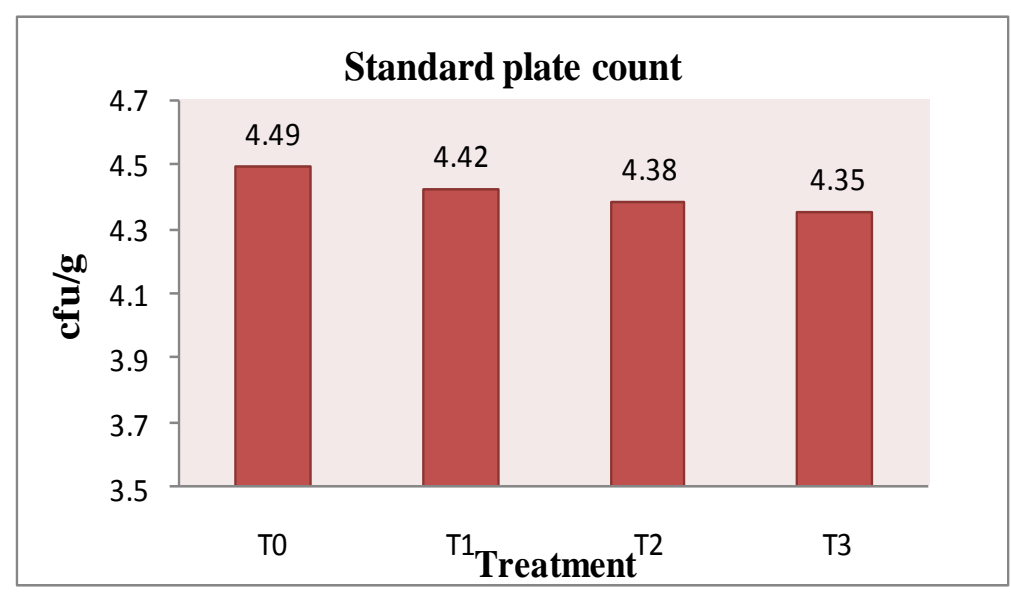

Fig.2 Changes in yeast and mold (cfu/g) of buttermilk added with different level of cinnamon powder

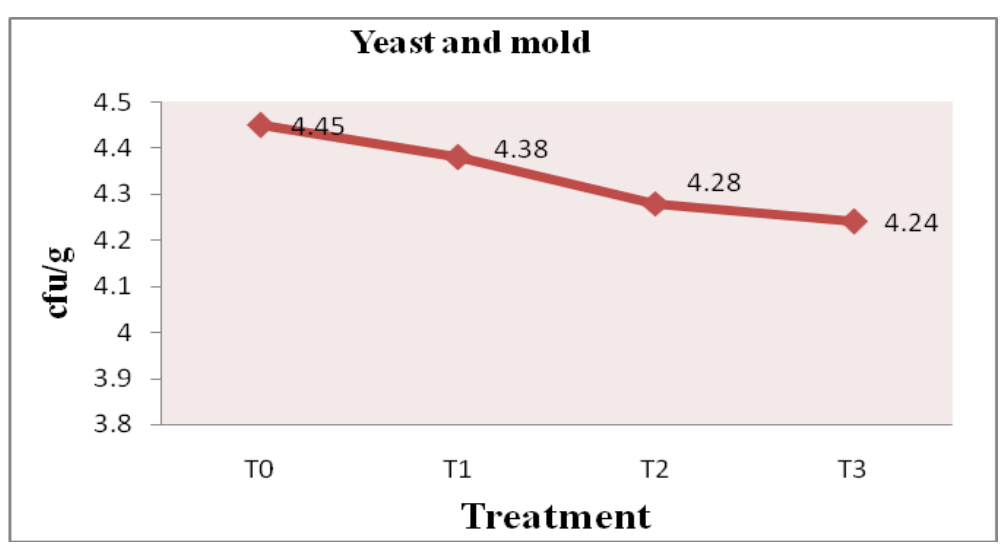




\section{Yeast and mold count}

The effect of cinnamon powder addition on yeast and mold count of buttermilk is shown in Fig. 2. The average values of yeast and mold in sample $\mathrm{T}_{0}, \mathrm{~T}_{1}, \mathrm{~T}_{2}$ and $\mathrm{T}_{3}$ were 4.45 , $4.38,4.28$ and 4.24 respectively. The maximum yeast and mold count found to be 4.45 in the sample $\mathrm{T}_{0}$ (control), whereas, the minimum of yeast and mold count was 4.24 in the sample $\left(\mathrm{T}_{3}\right)$. Vidanagamage (2016) reported lower yeast and molds count in butter added with cinnamon extract.

From above result it can be concluded that the addition of cinnamon into butter milk decrease the standard plate count (SPC) and yeast and mold count. Thus cinnamon powder can be used to enhance the shelf-life of buttermilk.

\section{References}

Agaoglu, S., Dostbil, N. and Alemdar, S. 2007. Antimicrobial activity of some spices used in the meat industry. Bulletin of the Veterinary Institute in Pulaway, 55: 53-57.

Almeida, D.R.F. and Regitano, A.B. 2000. Antioxidant level of rosemary and oregano ethanol extracts in soybean oil under thermal oxidation. Ciencia e Technologia de Alimentos, 20: 2.

Anon. 2003. Butter milk: A remedy for many diseases. Indian Dairyman, 55:21.

APHA.1992. Microbiological methods for dairy products. In Standard methods for examination of dairy products.16th edition. Marshall, R.T. Ed. American public health association, Washington, DC, 287- 307.

Aureli, P., Costantini, A., and Zolea, S. 1992. Antimicrobial activity of some plant essential oils against Listeria monocytogenes. Journal of food protection, 55(5): 344-348.
Chawla, K., and Kansal, V.K. 1983. Depression in hepatic glucose6phosphate dehydrogenase-6phosphogluconate dehydrogenase linked NADP+ reduction in rats fed with cow milk, dahi and acidophilus milk. Milchwissenschaft, 38(9): 536 537.

Cowan, M. M. 1999. Plant products as antimicrobial agents. Clinical microbiology reviews, 12(4): 564-582.

Deans, S. G., Noble, R. C., Hiltunen, R., Wuryani, W., and Penzes, L. G. 1995. Antimicrobial and antioxidant properties of Syzygium aromaticum (L.) Merr. and Perry: impact upon bacteria, fungi and fatty acid levels in ageing mice. Flavour and Fragrance Journal, 10(5):323-328.

Hunziker, O. F. (1923). Utilization of Buttermilk in the form of Condensed and Dried Buttermilk. Journal of Dairy Science, 6(1):1-12.

Maheshwari, K., and Chuhan. 2013. Cinnamon: An Imperative Spice for Human Comfort. International Journal of Pharmaceutical Research and BioScience, 2 (5):131-145.

Mann, G. V., and Spoerry, A. 1974. Studies of a surfactant and cholesteremia in the Maasai. The American journal of clinical nutrition, 27(5):464-469.

Sarkar, S. 2002. Nutritional and healthful aspects of cultured milk products-a review, Indian journal of Dairying Bioscience. 13: 1-9.

Sarkar, S. 2008. Innovations in Indian Fermented Milk Products. A Review Food Biotechnology, 22:78- 97.

Shelef, L. A. 1984. Antimicrobial effects of spices 1. Journal of food safety, 6(1): 29-44.

Souza, E. L. D., Stamford, T. L. M., Lima, E. D. O., Trajano, V. N., and Barbosa Filho, J. M. 2005. Antimicrobial effectiveness of spices: an approach for 
use in food conservation systems. Brazilian Archives of Biology and Technology, 48(4): 549-558.

Thakur, C.P.; and Jha, A.N. 1981. Influence of milk, yoghurt and calcium on cholesterol-induced atherosclerosis in rabbits. Atherosclerosis 39(2): 221-215.

Trivedi, J.L. 1971. Family Medicine. (Gharvaidu) 4th Edition. J. M. Mehta Publication, Bombay: 20-26.Vaidya, B.G. 1983. Arogya Prasthan, J.M. Mehta Publication, Bombay: 1- 20.
Vangalapati, M., Satya, N. S., Prakash, D. S., and Avanigadda, S. 2012. A review on pharmacological activities and clinical effects of cinnamon species. Research Journal of pharmaceutical, biological and chemical sciences, 3(1): 653-663.

Vidanagamage, S. A., Pathiraje, P. M. H. D., and Perera, O. D. A. N. 2016. Effects of cinnamon (Cinnamomum verum) extract on functional properties of butter. Procedia food science, 6:136142.

\section{How to cite this article:}

Sutar Pritee Sanjay, Shakeel Asgar, Diwakar Mishra, S. D. Kalyankar and Patil, M. R. 2020. Effect of Cinnamon Powder Addition on Microbial Quality of Fresh Buttermilk. Int.J.Curr.Microbiol.App.Sci. 9(10): 2005-2009. doi: https://doi.org/10.20546/ijcmas.2020.910.244 